\title{
NOTES.
}

\section{THE COTYLEDONS OF GINKGO BILOBA AND CYCAS}

REVOLUTA. Mr. Lyon, in discussing the phylogeny of the cotyledon in the journal Postelsia ( $190 \mathrm{I}$ ), has come to the conclusion that the so-called cotyledons of the Pteridophyta and Gymnosperms, with the probable exceptions of Ginkgo and the Cycads, are true foliage leaves.

The foliar nature of the 'cotyledons' of Ginkgo and the Cycads would seem from this still open to discussion. The alternative would be the interpretation of these cotyledons as feeders, the term applied by Prof. Bower to the absorptive organs of the Gnetaceae.

Apart from the obvious double structure of the absorptive organs in Ginkgo and Cycas, which clearly distinguishes them from the feeders of the Gnetaceae, and would suggest their foliar nature, there are other features which may, I think, be taken to indicate that they are much modified foliar organs. Among these characters one I have recently observed is the occurrence of stomata on these cotyledons.

In Ginkgo the cotyledons are surrounded by endosperm but not fused with it. Their inner surfaces are closely pressed together so that each appears semi-circular in transverse section; sometimes only the margins meet, and then the cotyledons appear almost crescentic in transverse section.

Stomata are found chiefly on the upper surface, while in the foliage leaves they occur on the lower side only. This may be explained either by supposing those on the under surface of the cotyledons to have disappeared owing to the absorptive function of that part of the cotyledons, or, if we assume that the cotyledons were at a former period in the history of the plant expanded above ground, the stomata on the upper surface may have been protected by closing movements of the cotyledons similar to those of Cucurbita.

[Annals of Botany, Vol. XVII. No. LXVIII. September, I903.] 
The guard-cells, which are smaller than the other epidermal cells, lie flush with the surface of the cotyledon; they contain large, deeply staining nuclei. In surface view they appear crescent-shaped, enclosing a small, round or slightly oval pore in the centre (Fig. 29 A). In transverse section it is seen that the pore opens into a small intercellular space which in some cases appears to be filled with loosecelled tissue.

The guard-cells are oval in transverse section and obliquely inclined towards one another at the surface, their walls are thicker than those of the neighbouring cells but do not seem to be cuticularized.

In Cycas revoluta the cotyledons are much thicker and narrower than those of Ginkgo; they are more closely connected with the surrounding endosperm and their inner flattened surfaces are fused together, so that the junction of the two can only be distinguished near the margin, where the epidermal layers are still marked out, and by the thickening of the cell-walls of a few smaller cells here and there in the central part.

In spite of this very considerable alteration which the cotyledons have undergone stomata are still recognizable in a transverse section of the cotyledon.

The guard-cells here are much smaller than the neighbouring cells, and of characteristic shape. They contain large, deeply staining nuclei, and their walls are very much cuticularized on what would be their outer surface if the cotyledons were not fused. A well-marked pore leads into an intercellular space below (Fig. $29 \mathrm{~B}$ ).

It is evident from the position of the stomata in Cycas revoluta that they cannot possess any functional value; probably they only indicate an ancestral condition when the cotyledons came above ground and functioned as ordinary foliage leaves.

In Ginkgo, however, where the cotyledons are not fused, there would be a layer of air between the two cotyledons, between which there often exists a considerable space, and here they might possibly have a respiratory function.

At all events, whether functional or not, their presence suggests that at one time the cotyledons of Ginkgo were withdrawn from the testa and expanded above ground, as is the case in most Gymnospermous seedlings.

There seems, therefore, good reason to regard the cotyledons of Cycadaceae and Ginkgoaceae as true foliage leaves, which have 
become hypogeal like those of Araucaria brasitiana, A. imbricata and A. Bidzoillii.

A.

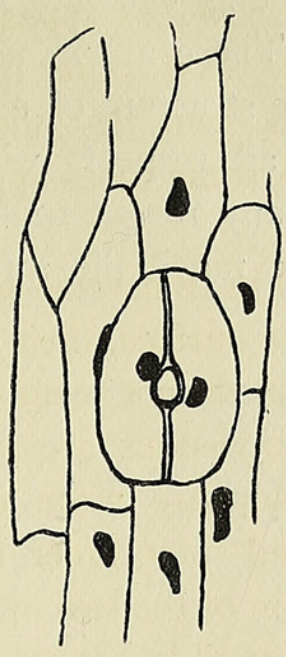

B.

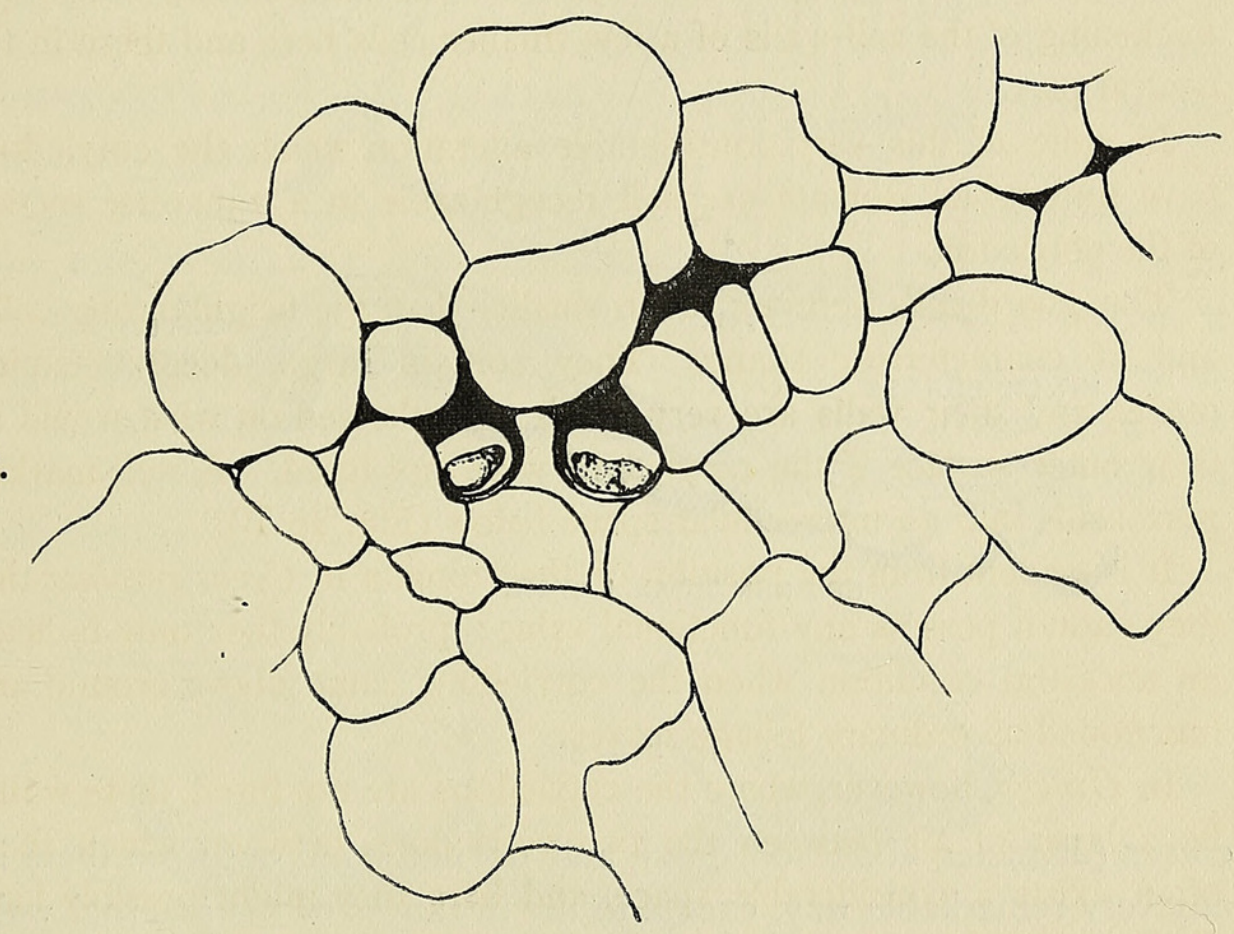

FIG. 29.

A. Portion of the upper surface of the cotyledon of Ginkgo, showing a stoma with distinct pore.

B. Portion of a section across the fused cotyledons of Cycas. The two guardcells of the stoma are distinctly separated and their outer walls are cuticularized. Cuticular thickening at other points indicates the line of junction of the two cotyledons.

\section{GRACE WIGGLESWORTH.}

Owens College, Manchester. 


\section{$2 \mathrm{BHL}$ Biodiversity Heritage Library}

Wigglesworth, Grace. 1903. "The cotyledons of Ginkgo biloba and Cycas revoluta." Annals of botany 17, 789-791. https://doi.org/10.1093/oxfordjournals.aob.a088944.

View This Item Online: https://www.biodiversitylibrary.org/item/235015

DOI: https://doi.org/10.1093/oxfordjournals.aob.a088944

Permalink: https://www.biodiversitylibrary.org/partpdf/318742

\section{Holding Institution}

Smithsonian Libraries

\section{Sponsored by}

Biodiversity Heritage Library

\section{Copyright \& Reuse}

Copyright Status: Not in copyright. The BHL knows of no copyright restrictions on this item.

This document was created from content at the Biodiversity Heritage Library, the world's largest open access digital library for biodiversity literature and archives. Visit BHL at https://www.biodiversitylibrary.org. 